\title{
МІСЦЕ ПРАВООХОРОННИХ ОРГАНІВ У СИСТЕМІ ОРГАНІВ ДЕРЖАВНОЇ ВЛАДИ
}

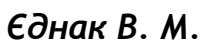

у статmі, на основі опрацювання наукових поглядів вчених та норм чинного законодавства України, визначено роль та місце правоохоронних органів у системі органів державної влади. Відзначено, що особливе місце правоохоронних органів в системі органів державної влади обумовлено їх функціональним призначенням. Так, основним напрямком роботи даних органів є реалізація правоохоронної функції, що знаходить свій прояв у діяльності із забезпечення прав, свобод та інтересів особи, протидіі та боротьби з правопорушеннями.

Ключові слова: правоохоронні органи, органи держав ної влади, прокуратура, поліція, законодавство.

В статье, на основе обработки научных взглядов ученых и норм действующего законодательства Украины, определена роль и место правоохранительных органов в системе органов государственной власти. Отмечено, что особое место правоохранительных органов в системе органов государственной власти обусловлено их функциональным назначением. Так, основным направлением работы данных органов является реализация правоохранительной функции, что находит свое проявление в деятельности по обеспечению прав, свобод и интересов лица, противодействия и борьбы с правонарушениями.

Ключевые слова: правоохранительные органы, органы государственной власти, прокуратура, полиция, законодательство.

In the article, on the basis of working out of scientific views of scientists and norms of the current legislation of Ukraine, the role and place of law enforcement bodies in the system of state authorities is determined. It is noted that the special place of law enforcement agencies in the system of state authorities is due to their functional purpose. It is determined that one of the main features that characterize law enforcement agencies is that: their activities are aimed at preventing and combating offenses, ensuring the rights, freedoms and interests of the person (the main direction of their activity), that is, performing law enforcement function of the state; they are represented exclusively by government bodies, and therefore non-governmental entities, NGOs, etc. cannot be included in their number. Thus, some of the scientists, defining the essence of law enforcement agencies as state, indicate that they are representatives of the executive power alone. It is concluded that law enforcement agencies occupy a special place in the system of public authorities, which indicates their role in such a system. Most of law enforcement agencies are representatives of the executive branch. However, some of these bodies, because of the specific nature of their legal status, cannot be attributed to any of the branches of government. The special place of law enforcement agencies in the system of public authorities is due to their functional purpose. Thus, the main focus of the work of these bodies is the implementation of law enforcement function, which is manifested in activities to ensure the rights, freedoms and interests of the individual, countering and combating offenses. It should be borne in mind that a separate law enforcement agency will exercise such a function in view of the range

Єднак В. М., 2019 of social relations within which it exercises its competence. This is what causes a significant number of law enforcement agencies in the system of public authorities. In aggregate, the importance of law enforcement agencies in the system of public authorities is given and determined: their activity is aimed at ensuring the functioning of relevant public institutions; they ensure the fulfillment of the tasks of the state as a whole and, consequently, the functioning of the state bodies responsible for their implementation; ensure the normal course of all public relations in the state.

Key words: law enforcement, public authorities, prosecutor's office, police, legislation.

Постановка проблеми та її актуальність. Сучасний етап розбудови української державності свідчить про необхідність кардинального реформування системи правоохоронних органів, діяльність яких $\epsilon$ запорукою побудови демократичного суспільства. Однак даний процес значно ускладнюється через відсутність нормативного визначення поняття «правоохоронний орган» та наявність чисельних суперечностей у теоретичних джерелах, у яких робиться спроба визначити необхідні та достатні ознаки даного феномена [1]. Саме тому встановлення ролі та значення правоохоронних органів у системі органів державної влади має першочергове значення в аспекті визначення шляхів підвищення ефективності їх діяльності, а отже, й забезпечення належного функціонування держави в цілому.

Аналіз останніх досліджень і публікацій. Окремі проблемні питання щодо функціонування правоохоронних органів та напрямків удосконалення їх діяльності неодноразово потрапляли в поле зору різних науковців. Зокрема їй приділяли увагу: О.М. Бандурка, А.П. Гель, Г.С. Семаков, С.П. Кондракова, В.Л. Федоренко, С.М. Кременчуцький, М.І. Мельник, М.І. Хавронюк, Ю.М. Грошевий, М.В. Руденко, В. М. Гірич, В.В. Долежан, М.В. Косюта та інші. Однак незважаючи на чималу кількість наукових розробок, у юридичній літературі відсутні комплексні наукові дослідження, присвячені визначенню місця правоохоронних органів у системі органів державної влади.

Саме тому метою статті є: визначити місце правоохоронних органів у системі органів державної влади.

Виклад основного матеріалу. В науковій літературі вказується, що правоохоронні органи - це спеціально уповноважені державні органи, які забезпечують дотримання та реалізацію прав і свобод громадян, законності та правопорядку згідно із встановленими законом правилами та процедурами відповідно до своєї компетенції [2, с. 50-51]. Доволі цікавим $є$ визначення сутності правоохоронних органів, запропоноване О.Ю. Загуменною в дослідженні, яке присвячене поняттю, ознакам, функціям та особливостям діяльності правоохоронних органів. На думку вченої, до правоохоронних органів належать державні органи, виконання якими однієї 
чи кількох головних правоохоронних функцій $\epsilon$ визначальним у їх діяльності, які у зв'язку з цим потребують специфічного матеріально-технічного й іншого забезпечення. До працівників цих структур законодавством пред'являються спеціальні вимоги. 3 метою ефективного виконання своїх обов'язків працівники згідно із законодавством наділяються різноманітними специфічними правами, вони мають відповідні пільги та зовнішні ознаки приналежності до правоохоронних органів, підлягають підвищеному правовому захисту [3, с. 150].

Проте вважаємо, що наведене визначення сутності досліджуваного явища вміщує в собі як його основні, так і другорядні ознаки. У такому разі, як цілком слушно зазначають учені-правознавці, воно стає занадто громіздким, набуває формально-юридичного характеру [4, с. 12]. При цьому не зовсім зрозуміло, що вчена має на увазі під терміном «головні правоохоронні функції». Також викликає сумнів позиція щодо віднесення до основних ознак правоохоронного органу обов'язкового використання його працівниками зовнішніх ознак приналежності до нього. Адже оперативні працівники відповідних правоохоронних органів під час виконання ряду оперативно-розшукових заходів з метою недопущення розкриття своєї особистості не використовують форменого одягу.

Отже, до одних з основних ознак, які характеризують правоохоронні органи, слід віднести те, що їх діяльність спрямована на запобігання та протидію правопорушенням, забезпечення прав, свобод та інтересів особи (основний напрямок їх діяльності), тобто виконання правоохоронної функції держави; вони представлені виключно державними органами, а тому до них не можна відносити недержавні формування, громадські організації тощо. При цьому зазначимо, що остання з названих вище ознак потребує деяких уточнень. Так, окремі з науковців, визначаючи сутність правоохоронних органів як державних, указують на те, що вони $\epsilon$ представниками виключно виконавчої влади.

Зокрема, С.Ф. Денисюк відмічає той факт, що окремі з учених-правознавців правоохоронні органи розглядають виключно з позиції їх віднесення до органів виконавчої влади [5, с. 119]. Також, як стверджує Т.О. Пікуля, правоохоронні органи входять до системи органів виконавчої влади й, у такий спосіб, відрізняються від суду та прокуратури [6, с. 71]. Дійсно, більшість правоохоронних органів будуть представниками саме виконавчої гілки влади. Так, як свідчить аналіз чинного національного законодавства, в якості прикладу правоохоронних органів, які $\epsilon$ представниками виконавчої влади можна назвати такі:

1. Національну поліцію України, яка відповідно до ст. 1 Закону України «Про Національну поліцію» від 2 липня 2015 року $\epsilon$ центральним органом виконавчої влади, який служить суспільству шляхом забезпечення охорони прав і свобод людини, протидії злочинності, підтримання публічної безпеки та порядку. Правовий статус Національної поліції України як центрального органу виконавчої служби визначено на рівні Положення «Про Національну поліцію», що затверджено постановою Кабінету Міністрів України від 28 жовтня 2015 року № 877.

2. Державну прикордонну службу України, яка відповідно до положень Закону України «Про Державну прикордонну службу України» від 3 квітня 2003 року $\epsilon$ правоохоронним органом спеціального призначення, на який покладається завдання щодо забезпечення недоторканності державного кордону та охорони суверенних прав України в їі прилеглій зоні та виключній (морській) економічній зоні. Правовий статус Державної прикордонної служби як центрального органу виконавчої влади визначено на рівні Положення «Про Адміністрацію Державної прикордонної служби України», що затверджено постановою Кабінету Міністрів України від 16 жовтня 2014 року № 533.

3. Державну міграційну службу України, яка відповідно до Положення «Про Державну міграційну службу України», що затверджено постановою Кабінету Міністрів України від 20 серпня 2014 року № 360, є центральним органом виконавчої влади, який реалізує державну політику у сферах міграції (імміграції та еміграції), в тому числі протидії нелегальній (незаконній) міграції, громадянства, реєстрації фізичних осіб, біженців та інших визначених законодавством категорій мігрантів.

4. Державну службу України з надзвичайних ситуацій, яка відповідно до Положення «Про Державну службу України з надзвичайних ситуацій», що затверджено постановою Кабінету Міністрів України від 16 грудня 2015 року № 1052, є центральним органом виконавчої влади, який реалізує державну політику у сфері цивільного захисту, захисту населення та територій від надзвичайних ситуацій i запобігання їх виникненню, ліквідації наслідків надзвичайних ситуацій, рятувальної справи, гасіння пожеж, пожежної та техногенної безпеки, діяльності аварійно-рятувальних служб, а також гідрометеорологічної діяльності [7].

5. Державну податкову службу України, яка відповідно до Положення «Про Державну податкову службу України», затвердженого постановою Кабінету Міністрів України від 6 березня 2019 року № 227, є центральним органом виконавчої влади, одним, із призначенням якого відбувається реалізація державної політики у сфері боротьби із правопорушеннями під час застосування податкового законодавства, а також законодавства з питань сплати єдиного внеску та законодавства з інших питань [8].

6. Державну митну службу України, яка відповідно до Положення «Про Державну митну службу України», що затверджено постановою Кабінету Міністрів України від 6 березня 2019 року № 227, є центральним органом виконавчої влади, який реалізує державну митну політику, державну політику у сфері боротьби з правопорушеннями під час застосування законодавства з питань державної митної справи [8].

7. Державне бюро розслідувань, яке відповідно до ст. 1 Закону України «Про Державне бюро розслідувань» від 12 листопада 2015 року є центральним органом виконавчої влади, який здійснює правоохоронну діяльність 3 метою запобігання, виявлення, припинення, розкриття та розслідування злочинів, віднесених до його компетенції [9].

8. Державну кримінально-виконавчу службу, яка відповідно до Закону України «Про Державну кримінально-виконавчу службу України» від 23 червня 2005 року здійснює правозастосовні та правоохоронні функції і складається з центрального органу виконавчої влади, який реалізує державну політику у сфері виконання кримінальних покарань, його територіальних органів управління, кримінально-виконавчої інспекції, установ виконання покарань, слідчих ізоляторів, воєнізованих формувань, навчальних закладів, закладів охорони 
здоров'я, підприємств установ виконання покарань, інших підприємств, установ та організацій, створених для забезпечення виконання завдань Державної кримінально-виконавчої служби України [10].

Наведені, а також деякі інші правоохоронні органи, як свідчить аналіз їх правового статусу та законодавчих основ їх функціонування, $\epsilon$ центральними органами виконавчої влади, які відповідно до ч. 1 ст. 1 Закону України «Про центральні органи виконавчої влади» від 17 березня 2011 року разом із міністерствами утворюють систему центральних органів виконавчої влади. При цьому, як свідчить аналіз чинного національного законодавства, здається можливим назвати ряд правоохоронних органів, через специфіку свого правового статусу не належать до жодної з гілок влади, в тому числі виконавчої. В якості прикладу таких органів назвемо наступні:

1. Прокуратура, яка згідно з положеннями Закону України «Про прокуратуру» від 14 жовтня 2014 року, становить єдину систему, що здійснює законодавчо закріплені функції задля захисту прав і свобод людини, загальних інтересів суспільства та держави.

2. Національна гвардія України, яка відповідно до ст. 1 Закону України «Про Національну гвардію України» від 12 березня 2014 року $є$ військовим формуванням із правоохоронними функціями, що призначено для виконання завдань із захисту й охорони життя, прав, свобод і законних інтересів громадян, суспільства й держави від злочинних та інших протиправних посягань, охорони громадського порядку та гарантії громадської безпеки, а також у взаємодії із правоохоронними органами - із гарантією державної безпеки та захисту державного кордону, припинення терористичної діяльності, діяльності незаконних воєнізованих або збройних формувань (груп), терористичних організацій, організованих груп і злочинних організацій [11].

3. Національне антикорупційне бюро України, яке згідно зі ст. 1 Закону України «Про Національне антикорупційне бюро України» від 14 жовтня 2014 року є державним правоохоронним органом, на який покладається попередження, виявлення, припинення, розслідування та розкриття корупційних правопорушень, віднесених до його підслідності, а також запобігання вчиненню нових.

4. Служба безпеки України, яка відповідно до положень Закону України «Про Службу безпеки України» від 25 березня 1992 року $\epsilon$ державним органом спеціального призначення з правоохоронними функціями, який забезпечує державну безпеку України, в межах визначеної законодавством компетенції здійснює захист державного суверенітету, конституційного ладу, територіальної цілісності, економічного, науково-технічного й оборонного потенціалу України, законних інтересів держави та прав громадян від розвідувально-підривної діяльності іноземних спеціальних служб, посягань із боку окремих організацій, груп та осіб, а також забезпечення охорони державної таємниці.

Висновки. Отже, аналіз наведеного матеріалу дозволяє стверджувати, що правоохоронні органи посідають особливе місце в системі органів державної влади, що вказує на їх роль у такій системі. Більшість із правоохоронних органів $\epsilon$ представниками органів виконавчої влади. Однак окремі з таких органів, з огляду на специфіку їх правового статусу, не можна віднести до жодної з гілок влади. Особливе місце правоохоронних органів у системі органів державної влади зумовлено їх функ- ціональним призначенням. Так, основним напрямком роботи даних органів $\epsilon$ реалізація правоохоронної функції, що знаходить свій прояв у діяльності із забезпечення прав, свобод та інтересів особи, протидії та боротьби із правопорушеннями. При цьому слід враховувати, що окремо взятий правоохоронний орган буде реалізовувати таку функцію з огляду на коло суспільних відносин, у межах яких він здійснює свою компетенцію. Саме це зумовлює значну кількість правоохоронних органів у системі органів державної влади. У сукупності наведене й зумовлює значення правоохоронних органів у системі органів державної влади: їх діяльність спрямована на забезпечення функціонування відповідних суспільних інституцій; вони забезпечують виконання завдань держави в цілому, а отже, й функціонування державних органів, відповідальних за їх реалізацію; забезпечують нормальний перебіг усіх суспільних відносин у державі.

\section{Література}

1. Шай Р. Я. Правоохоронна функція правової держави: теоретико-практичний аспект : автореферат дисертації на здобуття наукового ступеня кандидата юридичних наук : 12.00.01 - теорія та історія держави і права; історія політичних і правових учень / Роман Ярославович Шай ; Національний університет «Львівська політехніка». Львів, 2012. 20 c.

2. Куліш А. М. Правоохоронна система України: адміністративно-правові засади організації та функціонування : дис. ... доктора юрид. наук : 12.00.07 / Куліш Анатолій Миколайович. X, 2009. 433 с.

3. Загуменна Ю. О. Правоохоронні органи: поняття, ознаки, функції особливості діяльності. Право і безпека. 2010. № 3 (35). С. 145-150.

4. Пчелін В. Б. Перегляд адміністративних актів органів внутрішніх справ : дис. ... кандидата юрид. наук : 12.00.07 / Пчелін Віталій Борисович. Харків, 2011. 190 с.

5. Денисюк С. Ф. Громадський контроль за правоохоронною діяльністю в Україні: адміністративно-правові засади : дис. ... доктора юрид. наук : 12.00.07 / Денисюк Станіслав Федорович. К, 2010. 393 с.

6. Пікуля Т. О. Правоохоронні органи в механізмі держави України (теоретико-правові питання функціонування) : дис. ... канд. юрид. наук : 12.00 .01 / Пікуля Тетяна Олександрівна. К, 2004. 203 с.

7. Про затвердження Положення про Державну службу України з надзвичайних ситуацій : постанова Кабінету Міністрів України : від 16 груд. 2015 р. № 1052 Офіційний вісник України. 2015. № 102. Ст. 3514.

8. Про затвердження Положення про Державну податкову службу України та Державну митну службу України : постанова Кабінету Міністрів України : від 6 берез. 2019 р. № 227 Офіційний вісник України. 2019. № 26. Ст. 900.

9. Про Державне бюро розслідувань : Закон України : від 15 лист. 2015 р. № 794-VIII Відомості Верховної Ради України. 2016. № 6. С. 55.

10. Про Державну кримінально-виконавчу службу України : Закон України : від 23 черв. 2005 р. № 2713-IV Відомості Верховної Ради України. 2005. № 30. С. 409

11. Про Національну гвардію України : Закон України : від 12 бер. 2014 р. № 876-VII Відомості Верховної Ради України. 2014. № 17. С. 594.

Єәнак В. М., кандидат юридичних наук, доцент кафедри кримінального процесу Дніпропетровського державного університету внутрішніх справ 